\title{
A Study on the Role of National Housing Bank (NHB) in Housing Finance
}

\author{
C. Jeevanandam ${ }^{1}$ and M. Veerappan ${ }^{2}$ \\ ${ }^{1}$ Assistant Professor, Department of Commerce, ${ }^{2}$ Principal (Retd.), \\ ${ }^{1 \& 2}$ H. H. The Rajah’s College (Autonomous), Pudukkottai, Tamil Nadu, India \\ E-Mail: jeevacvignesh1966@gmail.com
}

\begin{abstract}
Housing is essential for decent living of a man. Providing housing for all is the prime motive of the Government of India. With a view to fulfill this objective, it instituted National Housing Bank during the year 1988 through which various housing finance companies are providing housing finances. The study is attempted to highlight the role played by the NHB in housing development of our Nation. NHB played a major role through its refinance activity to the housing finance institutions which are involving in housing finance activities.

Keywords: Housing Finance, NHB
\end{abstract}

\section{INTRODUCTION}

National Housing Bank (NHB) is an apex financial institution for housing started by the Government of India on $9^{\text {th }}$ July 1988 under the National Housing Bank Act, 1987. It is an apex agency to promote housing finance institutions both local and regional to provide financial and other supports to financial institutions which are involving in the housing finance. It registers regulates and supervises the Housing Finance Companies, and coordinates their activities with other regulators. With a view to strengthen the functions of NHB the Government of India has recently undertaken the NHB as its own entity. The entire ownership of the NHB was undertaken by the Government of India with an investment of Rs. 1450 crore. Formerly NHB was partially owned by the Reserve Bank of India and at present, it has been released as per the recommendations of Narashimman-II Committee. This initiative have been announced by the notification of Ministry of Finance on $29^{\text {th }}$ April 2019. The vision of the NHB is "Promoting inclusive expansion with stability in housing finance market". To fulfill the vision the NHB has adopted a mission as follows. "To harness and promote the market potentials to serve the housing needs of all segments of the population with the focus on low and moderate income housing". The vision and mission of the NHB has clearly indicated its objective to provide housing to all at affordable prices. With this motive NHB has framed its policies, principles, guidelines and procedures.

\section{A. Objectives of the $N H B$}

1. Promotion of sound, health, viable and cost effective housing finance system with a view to fulfill the housing requirements of all segments of the population.
2. Integrating housing finance system with the overall financial system of the economy.

3. Region wise network promotion to serve different income groups.

4. Making the housing credit more affordable by all income groups.

5. Regulation and supervision of the activities of housing finance company as per the provisions of the NHB Act 1987.

6. Facilitating the builders and constructors by supply of housing materials to strengthen the housing stock of the country.

B. Role of $N H B$

1. NHB promotes, establishes and supports the financial institutions which are involving in housing finance activities.

2. NHB grants loans against pledge of jewels or mortgage of properties and it also advances against various assets.

3. It provides guarantees to the housing finance companies for their loans.

4. It also deals with underwriting activities.

5. It deals with the bill of exchanges of the housing finance companies.

6. The purchase and sales, and mortgage of immovable properties are also done by the NHB.

7. It plays a vital role in establishing housing scheme for economically weaker section.

8. It coordinates the activities of LIC, GIC, UTI and other financial authorities which are providing housing finance.

9. Research and development activities of construction are being organized by NHB.

10. Extension of housing credit schemes are formulated by NHB.

\section{Housing Finance}

Housing is a vital component for every individual and it constitutes socio-economic status of a man. The problem of housing in India is huge because larger portion of population is still homeless. They are living without home both in urban and rural areas. The shortage of housing is a socio economic problem of the Nation and it needs wider 
attraction from the government and other responsible agencies. The housing will be the choices to augment infrastructure, household wealth, employment opportunities, education, health, eradication of poverty, women's participation in workforce, maternal and child mortality and many other wellbeing indicators. The tremendous growth of population and urbanization need a huge demand and supply both in terms of quantity and quality of housing segments in India.

\section{SCOPE OF THE STUDY}

The study is aimed at highlighting the role of the NHB towards development of housing in India. The NHB takes part by its operations of financing activities for housing through the various housing finance companies which are involved in the development of housing facilities. The entire housing finance system is monitored and regularized by NHB. Various housing schemes adopted and implemented by the housing finance companies are under the purview of NHB, and the shelterless population of India has been sizably reduced by the implementation of the housing development schemes by government and other related agencies.

\section{STATEMENT OF THE PROBLEM}

The shortage of housing is a perennial problem of developing country like India. A person who does not having a home faces various problems like social unrecognition, separated from the society, delayed marriage and other. This can be rectified by provision of affordable housing. The Government of India has organized an apex institution viz. National Housing Bank with an aim of providing housing for all. The study is attempted to detail the role of $\mathrm{NHB}$ in providing housing facilities to the homeless.

\section{OBJECTIVES OF THE STUDY}

The following are the objectives of the study

1. To enlighten the role played by NHB in the development of housing schemes.

2. To evaluate the performance of NHB.

\section{METHODOLOGY}

The study is based on secondary sources collected from journals, government reports and publication of NHB and related websites. A simple percentage technique was used for analysis and interpretations.

The table I explains the refinance disbursements of NHB through various financial institutions for the period 201516. Housing finance companies had played a vital role in the disbursements of housing finance which are refinanced by NHB. It amounted to Rs.10,852 crore (50.3\%). Scheduled Commercial Banks got refinance from NHB to the extent of Rs.10,275 crore (47.6\%).
TABLE I INSTITUTION-Wise REFINANCE DisbURSEMENTS FoR THE YeAR 2015 - 16 (AMOUNT IN RS. CRORE)

\begin{tabular}{|l|c|c|}
\hline \multirow{2}{*}{ Primary Lending Institutions } & \multicolumn{2}{|c|}{$\mathbf{2 0 1 5}-\mathbf{1 6}$} \\
\cline { 2 - 3 } & $\begin{array}{c}\text { Amount } \\
\text { Disbursed }\end{array}$ & $\begin{array}{c}\text { \% to } \\
\text { Total }\end{array}$ \\
\hline Housing Finance Companies & 10,852 & 50.3 \\
\hline Scheduled Commercial Banks & 10,275 & 47.6 \\
\hline Others & 463 & 2.1 \\
\hline \multicolumn{1}{c}{ Total } & 21,590 & 100.0 \\
\hline
\end{tabular}

Source: NHB Report on Trend and Progress of Housing in India, 2018

The refinance disbursement by other financial institutions like RRB, cooperative banks, etc. was very low due to the massive role played by Housing Financing Companies and Scheduled Commercial Banks.

TABle II Institution-Wise Refinance Disbursements For THE YeaR 2016 - 17 (AMOUNT IN RS. CRORE)

\begin{tabular}{|c|c|c|}
\hline \multirow[b]{2}{*}{ Primary Lending Institutions } & \multicolumn{2}{|c|}{$2016-17$} \\
\hline & $\begin{array}{c}\text { Amount } \\
\text { Disbursed }\end{array}$ & $\begin{array}{l}\% \text { to } \\
\text { Total } \\
\end{array}$ \\
\hline Housing Finance Companies & 16,779 & 74.0 \\
\hline Scheduled Commercial Banks & 5,696 & 25.1 \\
\hline Others & 209 & 0.9 \\
\hline Total & 22,684 & 100.0 \\
\hline
\end{tabular}

Source: NHB Report on Trend and Progress of Housing in India, 2018

The table II cited above reveals the refinance disbursements of NHB for the period 2016 - 17 through various financial institutions. HFCs dominated the housing finance sector by offering abundent quantum of housing loans than the other financial institutions namely Scheduled Commercial Banks, RRB, cooperative banks, etc. In the period 2016 - 17 they sanctioned and disbursed Rs. 16,779 crores which is 74 percent of the loan disbursed by all the housing finance companies.

TABle Iit Institution-Wise ReFinAnCE Disbursements For THE YeAR 2017 - 18 (AMOUNT IN Rs. CRORE)

\begin{tabular}{|l|r|r|}
\hline \multirow{2}{*}{ Primary Lending Institutions } & \multicolumn{2}{|c|}{$\mathbf{2 0 1 7}-\mathbf{1 8}$} \\
\cline { 2 - 3 } & $\begin{array}{c}\text { Amount } \\
\text { Disbursed }\end{array}$ & $\begin{array}{c}\text { \% to } \\
\text { Total }\end{array}$ \\
\hline Housing Finance Companies & 13,283 & 53.3 \\
\hline Scheduled Commercial Banks & 11,508 & 46.2 \\
\hline Others & 130 & 0.5 \\
\hline Total & 24,921 & 100.0 \\
\hline
\end{tabular}

Source: NHB Report on Trend and Progress of Housing in India, 2018

The refinance distribution of National Housing Bank during the period 2017 - 18 has been given in the above Table III. It expressed the active role of the Housing Finance Companies in fulfilling the housing finance requirement by their refinance distribution. The housing finance companies have received refinance from the NHB to the extent of Rs.13,283 crore. Scheduled Commercial Banks has also worked predominantly in the refinance distribution by 
availing Rs.11,508 crore from NHB. Very least contribution has been showed by the RRB, Cooperative Banks and other financial institutions in the refinance distribution.

\section{SUGGESTIONS}

The Government of India has wonderfully played in provising housing to the homeless. But the formalities and procedures adopted by the housing finance companies delayed the speedy implementation of the housing finance schemes. It should be simplified. The beneficiaries and borrowers cooperation is solicited in identifing the title of the land, approval procedures, etc.

\section{CONCLUSION}

By the implementation of the government sponsored housing schemes NHB contributed for elimination of shortages of housing to some extent. It enhanced the affordablity of housing facilities to the urban and rural poor. Further NHB predominently regulates the entire financial system of housing by its regulations. It contributes to the society by facilitating the decent living of human being by affordable housing schemes.

\section{REFERENCES}

[1] NHB Annual report, 2016.

[2] NHB Annual report, 2017.

[3] NHB Annual report, 2018

[4] NHB Report on Trend and Progress of Housing in India, 2018

[5] National Housing Bank (n.d.). Retrieved from https://nhb.org.in/about -us/\#Vision

[6] National Housing Bank (n.d.). Retrieved from https://nhb.org.in/wpcontent/uploads/2018/04/NHB_Inside_english_cdr_new14new_new. pdf

[7] National Housing Bank (n.d.). Retrieved from https://nhb.org.in/wpcontent/uploads/2019/02/Annual-Report-(2017-18) English.pdf

[8] Wikipedia (n.d.). Retrieved from https://en.wikipedia.org/wiki/nation al Housing Bank 